\title{
Dioxins Exposure and the Risk of Breast Cancer: A Systematic Review and Meta-analysis
}

\author{
Nematollah Jaafarzadeh Haghighi (iD ${ }^{1,2}$, Amal Saki Malehi (iD) ${ }^{3}$ and Zeinab Ghaedrahmat ${ }^{4,}$ \\ ${ }^{1}$ Environmental Technologies Research Center, Ahvaz Jundishapur University of Medical Sciences, Ahvaz, Iran \\ ${ }^{2}$ Department of Environmental Health Engineering, School of Health, Ahvaz Jundishapur University of Medical Sciences, Ahvaz, Iran \\ ${ }^{3}$ Department of Biostatistics and Epidemiology, School of Public Health, Ahvaz Jundishapur University of Medical Sciences, Ahvaz, Iran \\ ${ }^{4}$ Department of Environmental Health Engineering, Shoushtar faculty of Medical Sciences, Shoushtar, Iran \\ "Corresponding author: Shoushtar Faculty of Medical Sciences, Shoushtar, Iran. Email: z_rahmati4007@yahoo.com
}

Received 2021 May 29; Revised 2021 June 26; Accepted 2021 June 29.

\begin{abstract}
Context: Dioxins and dioxin-like chemicals composed of 419 compounds are a large group of compounds, including polychlorinated di-benzo-p-dioxins (PCDDs), dibenzofurans (PCDFs), and biphenyls (PCBs). Dioxins are extremely persistent in the environment and disperse in a great distance from the emission source, and bioaccumulation in the food chain is one of their critical properties. The incidence of breast cancer among Iranian women is about 30 to 35 per 100,000 cases. The present study is a systematic review of published studies in English language to discover the relationship between exposure to dioxin compounds and breast cancer.

Methods: We conducted a comprehensive literature review utilizing PubMed, Embase, Scopus, and ISI web of science databases. The MeSH-based keywords used included Organic Chemical (MeSH) OR Dioxins (MeSH) AND cancer (MeSH) OR Breast cancer (MeSH) AND Breast disease (MeSH).

Results: The review of the literature indicated a significant positive association between dioxins exposure and the risk of breast cancer. Only in one study, breast cancer mortality rate was reported in terms of exposure to dioxins, and standardized mortality rates (SMRs) were determined.

Conclusions: Although there were limitations in this study, statistical analyses in various epidemiological studies demonstrated that dioxins exposure is linked to an increased risk of breast cancer.
\end{abstract}

Keywords: Dioxins, Breast Neoplasm, Systematic Review, Organic Chemical

\section{Context}

Currently, 210 recognized dioxins (75 PCDDs and 135 PCDFs) have been recognized by the amount and location of chlorine molecules. Among them, 17 (7 PCDDs and 10 PCDFs) have been distinguished as harmful by the World Health Organization (WHO), and TCDD is the foremost harmful congener. In 1997, IARC classified TCDD as carcinogenic to humans. This classification was confirmed in 2009, with adequate population testing for all cancers, and restricted testing for lung cancer, soft tissue sarcoma, and non-lymphoma $(1,2)$. TCDD is not specifically genotoxic but may cause an increment in responsive oxygen species (ROS), and consequently, DNA harm and changes (3).

Previous studies have proposed that dioxins disturb estrogenic directions to the AhR and can have different impacts according to level of hormone (4-7). Dioxins demonstrate anti-estrogenic reactions within the proximity of estrogens through restraining estrogen-induced qualities and proteins $(8,9)$ and estrogenic impacts in the nonattendance of estrogens, through which dioxins actuate the translation of hormone-dependent qualities (9).

TCDD may be an organic pollutant (POP) (10) and bioaccumulate in animal and human nourishment systems. TCDD has more dissolvability in water, but it is exceedingly lipophilic and amasses in fat tissues. TCDD is identified in fat tissues, blood, and breast secretions $(11,12)$. Human exposure to dioxins is calculated based on noxious comparability leftovers (TEQ). All the 17 harmful dioxin congeners are given a harmful proportionality figure (TEF), according to its favoritism with the Alright recipient, this is weighted for the most part to TCDD. The TEQ of a mixture of congeners is calculated by multiplying individual levels of congeners by its TEF and summing the individual values. Dioxins are produced unintentionally during combustion 
processes involving a chlorine source such as incineration sources, cement kilns, wood-burning including domestic heating, diesel vehicles, coal-fired utilities, and crematoria, pulp, and paper mills, chemical manufacturing, and metal industry (13).

Dioxins are omnipresent contaminants within the environment, including surface water, groundwater, soil, and sediment. Dioxin exposure within the common populace is evaluated to be low; a survey assessed the TCDD blood concentration at $1.8 \mathrm{pg} / \mathrm{g}$ lipid (standard deviation $\mathrm{SD}=1.7$ ) within the common populace not directly exposed to dioxin emitting sources (109 studies published in 1989 2010 (14). IARC reported that around 90\% of dioxin introduction within the common populace happens through the swallowing of sullied nourishment, due to the accumulation of them within the nourishment chain and in nourishments such as high-fat dairy items, eggs, and fats and fish (IARC 2012c).

Indeed, higher exposures happen due to mechanical mishaps, the most important of which I the blast of ICMESA chemical plant in Seveso (Italy, July 1976), causing the discharge of an expansive sum of TCDD of up to $30 \mathrm{~kg}$ over $18.1 \mathrm{~km}^{2}$ within the polluted zone (15). Due to their potential carcinogenicity and estrogen-mimicking properties demonstrated in experimental studies, dioxins are suspected of causing breast cancer $(16,17)$. This is a systematic review with emphasis on English-language published studies to discover the relationship between exposure to dioxin-related compounds and breast cancer.

The incidence of breast cancer among Iranian women is about 30 to 35 cases per 100,000 . This is a systematic review of published studies in English language to discover the relationship between exposure to dioxin-related compounds and breast cancer.

\section{Methods}

\subsection{Data Source}

For this systematic literature review, we searched PubMed, Scopus, Web of Science, EMBASE, and Cochrane library databases for articles published from April 1968 to April 2020. The keywords used (MeSH) included Organic Chemical (MeSH) OR Dioxins (MeSH) AND cancer (MeSH) OR Breast Neoplasm (MeSH) AND Breast disease (MeSH). All English published articles that reported breast cancer due to exposure to dioxins were used in this study. The inclusion criteria in this study were as follows: (I) cohort studies and case-control studies; (II) human subject research; and (III) studies with the confirmation of carcinogenicity.
The exclusion criteria were as follows: (I) case reports, (II) news, (III) letters, (IV) review articles, and (V) abstracts without full texts because of the limited data. For studies with multiple results, only data on adverse outcomes was analyzed. Moreover, we focused on human health and studies whose full text was available free of charge or online through institutional subscriptions.

\subsection{Data Extraction}

Data extraction was conducted independently by two researchers. The endpoints of this study were all breast cancer incidences and mortalities due to the various forms of exposure to dioxins as most of the included studies adopted. The information extracted from each study included author's name, title, year of publication, population size of the study group, study area, and study results. In the process of data extraction, any disagreement between the researchers was resolved by unanimity. This meta-analysis was designed and conducted according to the PRISMA statement (Figure 1) (18).

\subsection{Data Synthesis and Statistical Analysis}

The incidence rate of breast cancer was independently estimated in cohort studies. The odds ratios (OR) and 95\% confidence intervals $(\mathrm{CI})$ were calculated for case-control studies. We used the Cochrane $\mathrm{Q}$ and $\mathrm{I}^{2}$ statistics to assess heterogeneity and inconsistency, respectively. Furthermore, funnel plot supported with Egger's regression test was performed to assessed small-study effects. No planned subgroup analysis was performed because of the small number of studies and insufficient reported data. STATA12 software (STATA Corporation, College Station, Texas) was used for statistical analysis. A P-value of less than 0.05 was considered statistically significant.

\section{Results}

\subsection{Study Description}

After a comprehensive search, 416 articles were retrieved, 316 of which were excluded because the titles were irrelevant, 62 articles were excluded for being duplicates, and 17 articles were excluded for being review articles. Overall, 38 articles were included for further consideration, 28 of which were excluded after full review. Finally, this systematic review study included nine studied for further analysis, including four cohort studies, three casecontrol studies, and two cross-sectional studies. 


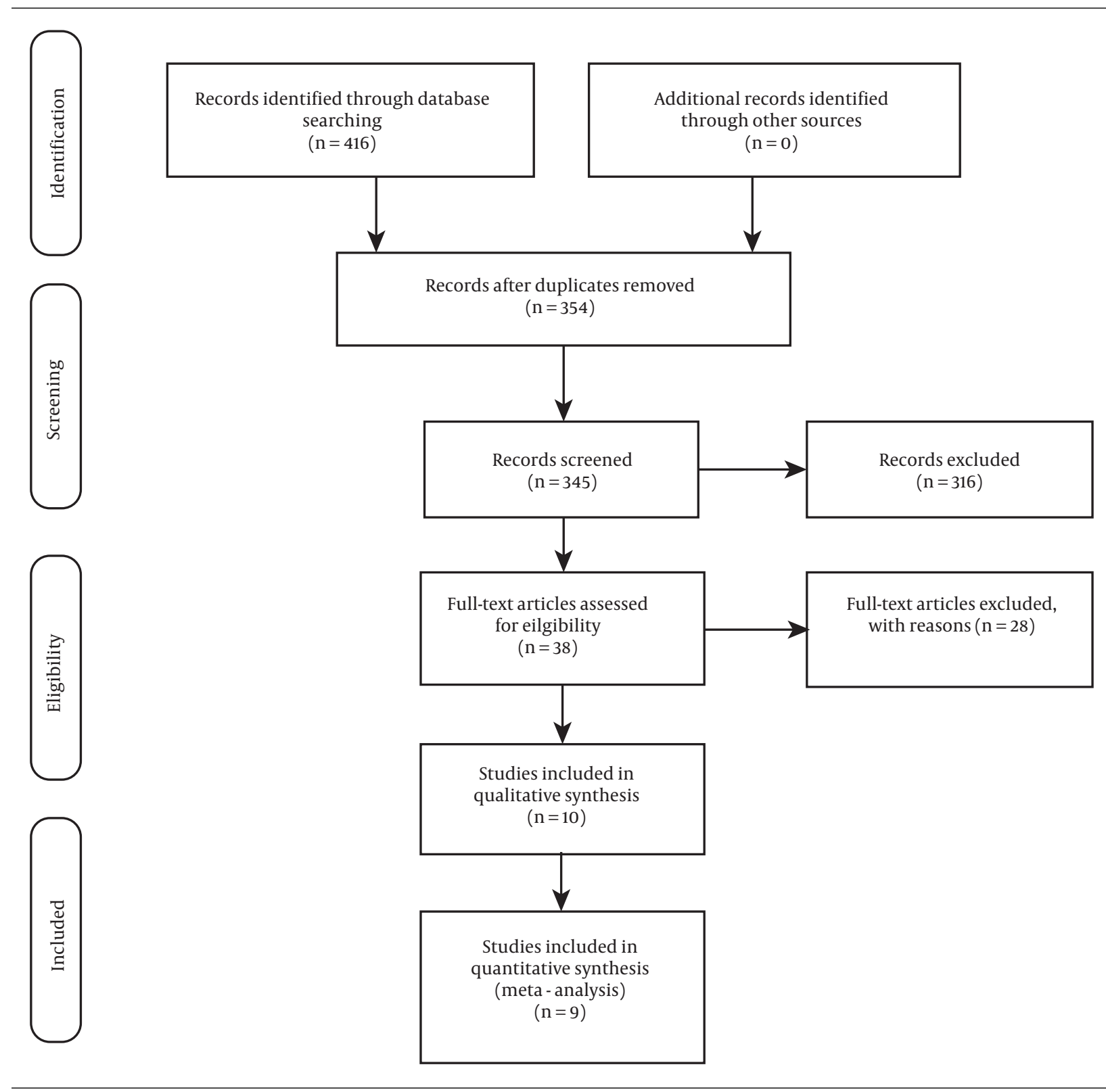

Figure 1. The flow diagram for selecting studies

Of the nine studies, two were performed in the USA, three in France, two in Germany, one in Italy, and one in Taiwan (19-28). There were different dioxin exposure sources, such as occupational and non-occupational exposure and industrial explosion. The general characteristics of the selected studies are presented in Table 1 . Among the included studies, eight investigated the association between exposure to dioxins and the risk of breast cancer incidence, and one study evaluated breast cancer mortality.

\subsection{Dioxin Exposure and Breast Cancer}

The effects of dioxins on the incidence of breast cancer were investigated in the USA, France, and Germany. The most frequently reported result was the association of breast cancer incidence and mortality with dioxins exposure. Some articles categorized the results by gender (Table 1).

In a study in Midland, Saginaw, and Bay counties, Michigan, USA, high levels of dioxin contamination were found in the 100-year-old Midland floodplain and the 


\begin{tabular}{|c|c|c|c|c|c|c|c|c|c|c|c|}
\hline References & $\begin{array}{l}\text { Study Pop- } \\
\text { ulation }\end{array}$ & $\begin{array}{l}\text { Breast } \\
\text { Cancer } \\
\text { Cases }\end{array}$ & $\begin{array}{l}\text { Number of } \\
\text { Cases }\end{array}$ & $\begin{array}{c}\text { Ways of } \\
\text { Exposure }\end{array}$ & P-Values & $\begin{array}{l}\text { Standardized } \\
\text { Ratios } \\
\text { (SMRs) }\end{array}$ & $\begin{array}{l}\text { Odd Ratio } \\
\text { (95\% Con- } \\
\text { fidence } \\
\text { Interval) }\end{array}$ & $\begin{array}{l}\text { Crude } \\
\text { Hazard } \\
\text { Ratio }(95 \% \\
\text { CI) }\end{array}$ & TEQ & $\begin{array}{l}\text { Type of } \\
\text { Study }\end{array}$ & Finding \\
\hline $\begin{array}{l}\text { Dai and Oyana } \\
(24), 2008\end{array}$ & $\begin{array}{l}\text { Michigan, } \\
\text { USA }\end{array}$ & Female & 4,604 & Soil & $<0.0001$ & - & $1-2.45$ & $\cdot$ & . & $\begin{array}{l}\text { Ecological } \\
\text { study }\end{array}$ & $\begin{array}{l}\text { The odds ratio also points to a } \\
\text { statistically significant (= } \\
0.05) \text { increase in breast } \\
\text { cancer rates as women age, as } \\
\text { well as a higher disease } \\
\text { burden in the Midland and } \\
\text { the neighboring areas, which } \\
\text { are adjacent to } \\
\text { dioxin-polluted areas. }\end{array}$ \\
\hline $\begin{array}{l}\text { Viel et al. (25), } \\
2008\end{array}$ & France & Female & 434 & $\begin{array}{l}\text { Non- } \\
\text { occupational } \\
\text { exposure }\end{array}$ & $0.17-0.21$ & . & $\begin{array}{l}0.88-1.06 \\
\text { for women } \\
\text { aged } 20-59 \\
\text { years } 0.31-1 \\
\text { for women } \\
\text { aged } 60 \\
\text { years and } \\
\text { over }\end{array}$ & - & & $\begin{array}{l}\text { Case- } \\
\text { control } \\
\text { study }\end{array}$ & $\begin{array}{l}\text { There was not an increase or } \\
\text { decrease in the risk of dioxin } \\
\text { exposure among women } \\
\text { under } 60 \text { years of old. women } \\
\text { over } 60 \text { years old who lived in } \\
\text { the most exposed zone, on } \\
\text { the other hand, were } 0.31 \\
\text { times less likely to develop } \\
\text { invasive breast cancer }(95 \% \\
\text { confidence interval, } 0.08 \text { - } \\
0.89 \text { ). }\end{array}$ \\
\hline $\begin{array}{l}\text { Warner et al. } \\
(26), 2002\end{array}$ & Seveso, Italy & $\begin{array}{l}\text { Seveso } \\
\text { Women's } \\
\text { Health } \\
\text { study }\end{array}$ & 981 & $\begin{array}{l}\text { Industrial } \\
\text { explosion }\end{array}$ & $0.05-0.07$ & - & - & $2.1-3.3$ & - & $\begin{array}{l}\text { Cohort } \\
\text { study }\end{array}$ & $\begin{array}{l}\text { The hazard ratio for breast } \\
\text { cancer was linked with a } \\
\text { 10-fold increase in serum } \\
\text { TCDD levels. logio TCDD was } \\
\text { dramatically enhanced to } 2.1 \\
\text { (95\% confidence interval, } 1.0 \text { - } \\
4.6 \text { ) using Cox proportional } \\
\text { hazards models. }\end{array}$ \\
\hline $\begin{array}{l}\text { Wang et al. (27), } \\
2006\end{array}$ & Taiwan & $\begin{array}{l}\text { Female 25 - } \\
34 \text { years }\end{array}$ & 50 & $\begin{array}{l}\text { Non- } \\
\text { occupational } \\
\text { exposure }\end{array}$ & - & - & & - & $4.84-5.97$ & $\begin{array}{l}\text { Cohort } \\
\text { study }\end{array}$ & $\begin{array}{l}\text { The presence of PCDDs/PCDFs } \\
\text { in the body may be linked to } \\
\text { altered estrogen catabolism. } \\
\text { Our findings imply that } \\
\text { PCDD/PCDF exposure has a } \\
\text { considerable impact on } \\
\text { estrogen metabolism. As a } \\
\text { result, when employing the } \\
\text { OH-E2 ratio as a breast cancer } \\
\text { marker, PCDD/PCDF exposure } \\
\text { must be taken into account. }\end{array}$ \\
\hline $\begin{array}{l}\text { Danjou et al. } \\
\text { (19), 2015 }\end{array}$ & France & Female & 63,830 & $\begin{array}{l}\text { Dietary } \\
\text { dioxin } \\
\text { exposure }\end{array}$ & 0.0463 & - & . & $0.45-0.96$ & - & $\begin{array}{l}\text { Cohort } \\
\text { study }\end{array}$ & $\begin{array}{l}\text { In general, no link was } \\
\text { established to estimate the } \\
\text { relationship between dietary } \\
\text { dioxin exposure and breast } \\
\text { cancer risk in E3N women. To } \\
\text { see if low-dose dioxin } \\
\text { exposure is linked to BC risk, } \\
\text { more research should be } \\
\text { done on both dietary and } \\
\text { environmental exposures. }\end{array}$ \\
\hline $\begin{array}{l}\text { Reynolds et al. } \\
(20), 2005\end{array}$ & $\begin{array}{l}\text { California, } \\
\text { USA }\end{array}$ & Female & 79 & $\begin{array}{l}\text { Non- } \\
\text { occaptional } \\
\text { exposure }\end{array}$ & 0.36 & . & $\begin{array}{l}0.47-3.16 \\
\text { for second } \\
\text { tertiles } \\
0.64-4.12 \\
\text { for third } \\
\text { tertiles }\end{array}$ & - & & $\begin{array}{l}\text { Case- } \\
\text { control } \\
\text { study }\end{array}$ & $\begin{array}{l}\text { The presence of PCDD/PCDFs } \\
\text { in adipose tissue was not } \\
\text { linked to the risk of breast } \\
\text { cancer. More research is } \\
\text { needed among women of } \\
\text { color, who may have larger } \\
\text { quantities of these chemicals } \\
\text { in their bodies. }\end{array}$ \\
\hline $\begin{array}{l}\text { Manuwald et al. } \\
\text { (21), 2012 }\end{array}$ & $\begin{array}{l}\text { Hamburg, } \\
\text { Germany }\end{array}$ & $\begin{array}{l}\text { Female and } \\
\text { male }\end{array}$ & $\begin{array}{l}(1191 \\
\text { men/398 } \\
\text { women }\end{array}$ & $\begin{array}{l}\text { Occupational } \\
\text { exposure }\end{array}$ & - & 1.21 to 1.56 & . & - & - & $\begin{array}{l}\text { Cohort } \\
\text { study }\end{array}$ & $\begin{array}{l}\text { Breast cancer mortality (ICD-9 } \\
\text { 174) increased in women } \\
\text { (SMR14.186, 95\% CI 1.12 to } 2.91 \text { ). }\end{array}$ \\
\hline $\begin{array}{l}\text { Korner et al. } \\
\text { (22),1994 }\end{array}$ & Germany & $\begin{array}{l}\text { Mammary } \\
\text { carcinoma } \\
\text { tissue }\end{array}$ & 8 & $\begin{array}{l}\text { Non- } \\
\text { occupational } \\
\text { exposure }\end{array}$ & & & & & - & $\begin{array}{l}\text { Ecological } \\
\text { study }\end{array}$ & $\begin{array}{l}\text { Despite having comparable } \\
\text { congener profiles, the } \\
\text { concentrations in four } \\
\text { axillary adipose tissue } \\
\text { samples that corresponded to } \\
\text { cancer samples were almost } \\
40 \% \text { lower. }\end{array}$ \\
\hline $\begin{array}{l}\text { Villeneuve et al. } \\
(23), 2010\end{array}$ & France & $\begin{array}{l}\text { Female and } \\
\text { male }\end{array}$ & $\begin{array}{l}104 \text { cases } \\
\text { and } 1901 \\
\text { controls }\end{array}$ & $\begin{array}{l}\text { Occupational } \\
\text { exposure }\end{array}$ & 0.14 & - & $1.0-4.4$ & $\cdot$ & - & $\begin{array}{l}\text { Case- } \\
\text { control } \\
\text { study }\end{array}$ & $\begin{array}{l}\text { The increased incidence of } \\
\text { male breast cancer in } \\
\text { particular vocations revealed } \\
\text { probable mammary } \\
\text { carcinogens in the } \\
\text { environment. }\end{array}$ \\
\hline
\end{tabular}

Titabawasi River and, which showed a significant relationship with high incidence rates of breast cancer in Midland and polluted areas. In another study in Germany, concentration and profile of PCDDs and PCDFs in mammary carcinoma tissues were investigated.

\subsection{Case-Control studies}

Case-control studies were conducted to evaluate the link between dioxin exposure and breast cancer incidence $(20,23,25)$. There were three case-control studies with a non-significant heterogeneity between studies $\left(\chi^{2}=5.74\right.$, $\mathrm{P}=0.057$; Figure 2). However, because of substantial $\mathrm{I}^{2}=$ 
65.1\%, the Der Simonian and Laird's method was applied as a random-effect model for appraising the overall OR (Figure 3). The obtained pooled $\mathrm{OR}=1.03$ (95\% CI ( $0.57-1.86)$, $\mathrm{P}=0.93$ ) was non-significant. In addition, Egger's test indicated that publication bias might not have a significant influence on the pooled estimation $(\mathrm{P}=0.37)$.

In the study of Veil et al. (25), the association between dioxins and breast cancer risk was reported. Breast cancer cases, which were extracted from Doubs cancer registry, were women diagnosed from 1996 to 2002, aged 20 and above, and residing in the study area at the time of diagnosis. In France, among women under 60 years of age, no breast cancer risk was found for any dioxin exposure, and women aged over 60 years living in dioxin exposed areas were 0.31 times less likely (95\% confidence interval, 0.08 - 0.89) to have an increased breast cancer risk (25). Another case-control study in the San Francisco Bay Area, was conducted among 79 women with invasive breast cancer and 52 controls with benign breast disease. This study determined the levels of organochlorines measured in the breast adipose tissue of women undergoing surgical breast biopsy (20). In another case-control study in eight European countries, 104 cases and 1901 controls were observed. This multi-center case-control study determined the occupational risk factors for male breast cancer (23).

\subsection{Cohort Studies}

Cohort studies have been conducted to evaluate the relationship between dioxins exposure and breast cancer in Italy, France, Germany, and Taiwan (19, 21, 26, 27). The association between dioxins exposure and breast cancer is shown in Table 2 . In Italy, 981 breast cancer cases, in France 63830 cases, and in Germany 1191 men and 398 women with breast cancer were observed $(19,21,26)$.

In Taiwan, 50 pregnant women 25 - 34 years of age were investigated for the risk of breast cancer (27). For men, overall mortality (ICD9 1999)(SMR:1.14, 95\% CI:1.06 to 1.23), increased cancer mortality (SMR: 1.37, 95\% CI: 1, 21 to 1.56). For women, breast cancer mortality increased (ICD9 174) (SMR:1.86, 95\% CI:1.12 to 2.91(21). The Cox proportional hazards model indicated that the breast cancer risk ratio $\left(\log _{10}\right.$ TCDD) related to elevated serum TCDD levels raised to 2.1 (95\% confidence interval, 1.0 - 4.6)(26).

The pooled estimation of incidence was 7\% (95\% CI (1\%$16 \%), \mathrm{P}<0.001)$. However, there was substantial heterogeneity between studies $\left(\mathrm{I}^{2}=99.4 \%, \chi^{2}=592.4, \mathrm{P}<0.001\right.$; Figures 4 and 5). A sensitivity analysis excluding the study by Wang et al. (27) had a minimal effect on the heterogene- ity between studies $\left(\mathrm{I}^{2}=98.9 \%, \chi^{2}=197.5, \mathrm{P}<0.001\right)$. The Egger test was also used to evaluate the effectiveness of small studies. The results indicated that publication bias might not have a significant influence on incidence rate pooled estimation $(\mathrm{P}=0.68)$.

\section{Discussion}

Various studies have shown that exposure to chemicals is associated with the risk of breast cancer. Spatial grouping of breast cancer morbidity near polluted areas proposes that there are significant factors contributing to the burden of disease in women that should be considered further in future works (24). In recent years, special attention has been paid to the carcinogenic effect of pseudoestrogen compounds such as dioxins in carcinogens on various organs including the breast $(20,23,29)$. So far, the studies of dioxins in soil have shown that breast cancer incidence is specifically related to soil contamination by dioxins (24).

This meta-analysis summarized the results of four cohort studies, three case-control studies, and two crosssectional studies $=$ conducted on the relationship between dioxins and breast cancer incidence and mortality. Reports of Macon and Fenton (29), Viel et al. (25), Warner et al. (26), Wang et al. (27), Danjou et al. (19), Reynolds et al. (20), Korner et al. (22), Villeneuve et al. (23), and Danjou et al. (28) indicated a significant positive association between dioxins exposure and breast cancer risk. Only in one study, breast cancer mortality rates were reported in terms of exposure to dioxins and standardized mortality rates (SMRs) were determined (21). Although there were few cases, but the low P-values showed that these findings were not accidental. The results of these studies showed that individuals exposed to dioxins through a variety of sources are at a significantly increased risk of breast cancer. Findings of the present study confirmed the carcinogenicity of dioxin compounds in previous studies. In addition, these studies draw researchers' attention to the risk of breast cancer mortality in exposed individuals.

Based on the results of these studies, the risk of breast cancer mortality in women is higher than in men (ICD-9 174) $(\mathrm{SMR}=1.86,95 \% \mathrm{CI} 1.12$ to 2.91$)$. For men, the risk of cancer mortality had increased (21). The risk of breast cancer in male vehicle mechanics due to occupational exposure to dioxins was increased $(\mathrm{OR}=2.1,95 \% \mathrm{CI} 1.0$ to 4.4$)(23)$. Based on the results of this meta-analysis, no relationship exists between dietary dioxin exposure and breast cancer risk in women. Future works should address both dietary and en- 
Study

ID
$\%$

OR $(95 \% \mathrm{CI}) \quad$ Weight

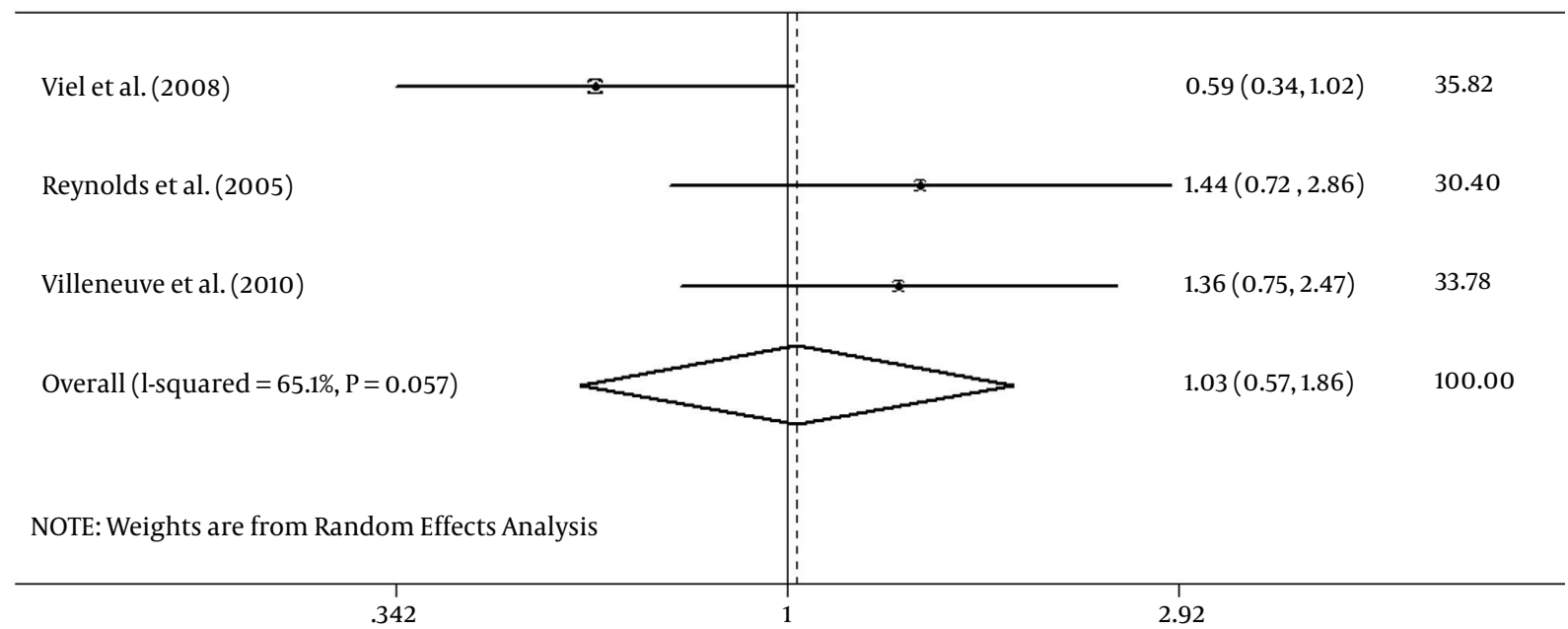

Figure 2. Forest plot for the association between dioxins exposure and breast cancer in the case-control studies

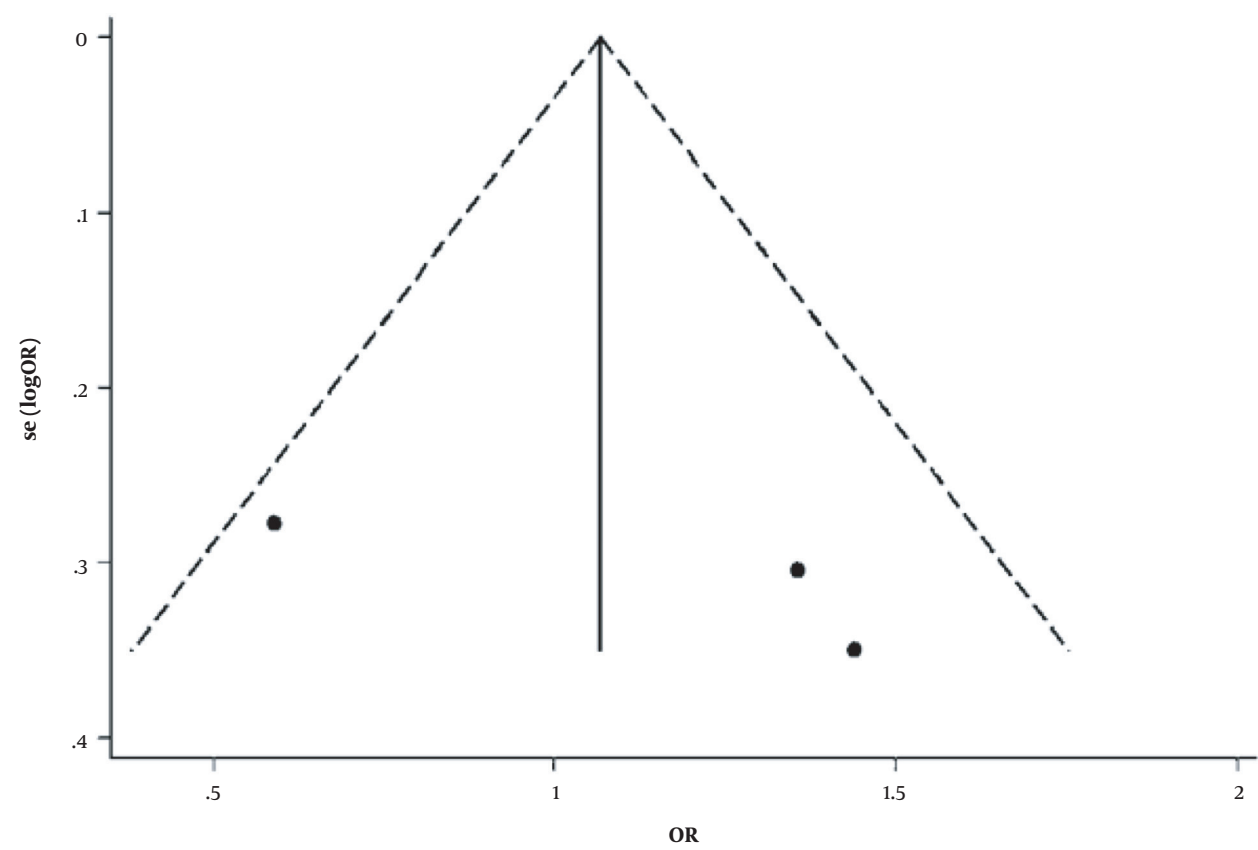

Figure 3. Funnel plot for dioxins exposure and breast cancer (funnel histogram with false $95 \%$ confidence limits) in the case-control studies 


\begin{tabular}{|c|c|c|c|c|c|c|}
\hline Reference & $\begin{array}{c}\text { Number of Cases and } \\
\text { Control }\end{array}$ & Risk Estimate (95\% CI) & Design & Outcome & Adjustment Factors & Age Range, y \\
\hline Viel et al. (25), 2008 & $453 / 2170$ & $\begin{array}{l}\text { OR: } 0.88 \text { - } 1 \text { for aged } 20- \\
59 \text { years OR: } 0.31-1 \text { for } \\
\text { aged } 60 \text { years and over }\end{array}$ & Case-control & Incidence & Age and sex & $20-59$ and 60 and over \\
\hline Warner et al. (26), 2002 & 981 & HR: 1 - 4.6 & Cohort & Incidence & Age and sex & $0-40$ \\
\hline Danjou et al. (19), 2015 & 63,830 & HR: $0.45-0.96$ & Cohort & incidence & Age and sex & 50 \\
\hline $\begin{array}{l}\text { Reynolds et al. (20), } \\
2005\end{array}$ & $79 / 52$ & $\begin{array}{c}\text { OR: } 0.47-3.16 \text { for second } \\
\text { tertiles; OR: } 0.64-4.12 \text { for } \\
\text { third tertiles }\end{array}$ & Case-control & Incidence & Age and sex & $<40$ to $>60$ \\
\hline $\begin{array}{l}\text { Manuwald et al. (21), } \\
2012\end{array}$ & 1191 men/398 women & SMRs: 1.21 - 1.56 & Cohort & Mortality & Sex & - \\
\hline $\begin{array}{l}\text { Villeneuve et al. (23), } \\
2010\end{array}$ & $104 / 1901$ & OR: $1.0-4.4$ & Case-control & Incidence & Age & $<40$ to $>65$ \\
\hline Wang et al. (27), 2006 & 50 & TEQ: $4.84-5.97$ & Cohort & Incidence & Age and sex & $25-34$ \\
\hline
\end{tabular}

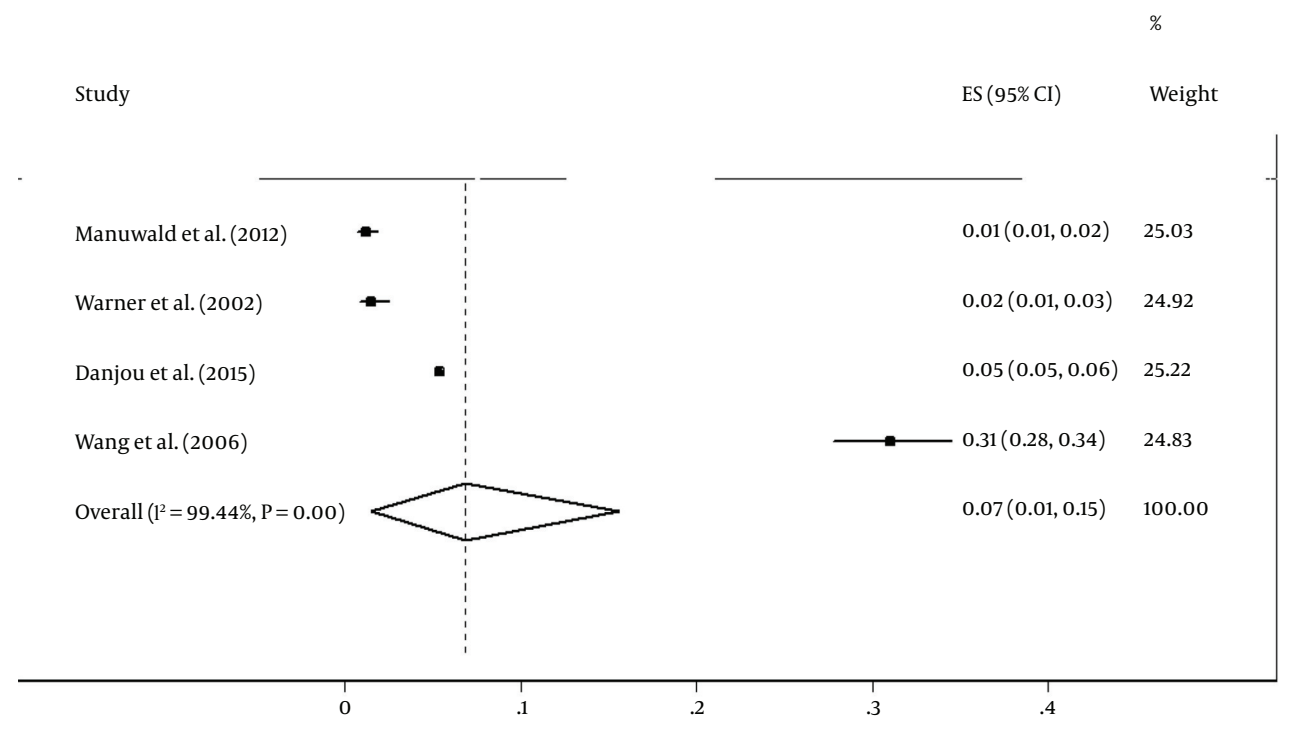

Figure 4. Forest plot for the association between dioxins exposure and breast cancer in cohort studies

vironmental exposures to investigate whether dioxin exposure is related to the risk of breast cancer (19).

There are some limitations to this review that need to be addressed. The included studies were limited to peerreviewed published articles in English. The English language criterion could have led to the selection of extensive research performed in English-speaking countries, including the United States, Canada, the United Kingdom, and Australia. By restricting the search to studies that specifically focus on breast cancer, we may have missed studies with the a more general title "cancer" in the headline review. However, the references of the included articles were also searched to minimize the possibility of omissions in a large number of studies.

\section{Conclusions}

This meta-analysis included nine studied including four cohort study, three case-control studies, and two cross sectional studies. These studies were conducted in different geographical locations such as Taiwan, USA, France, and Germany. Most of the studies were cohort and casecontrol studies. Reports of various studies indicated a significant positive association between dioxin exposure and the risk of breast cancer. Only in one study, breast cancer mortality rates were reported in terms of exposure to 


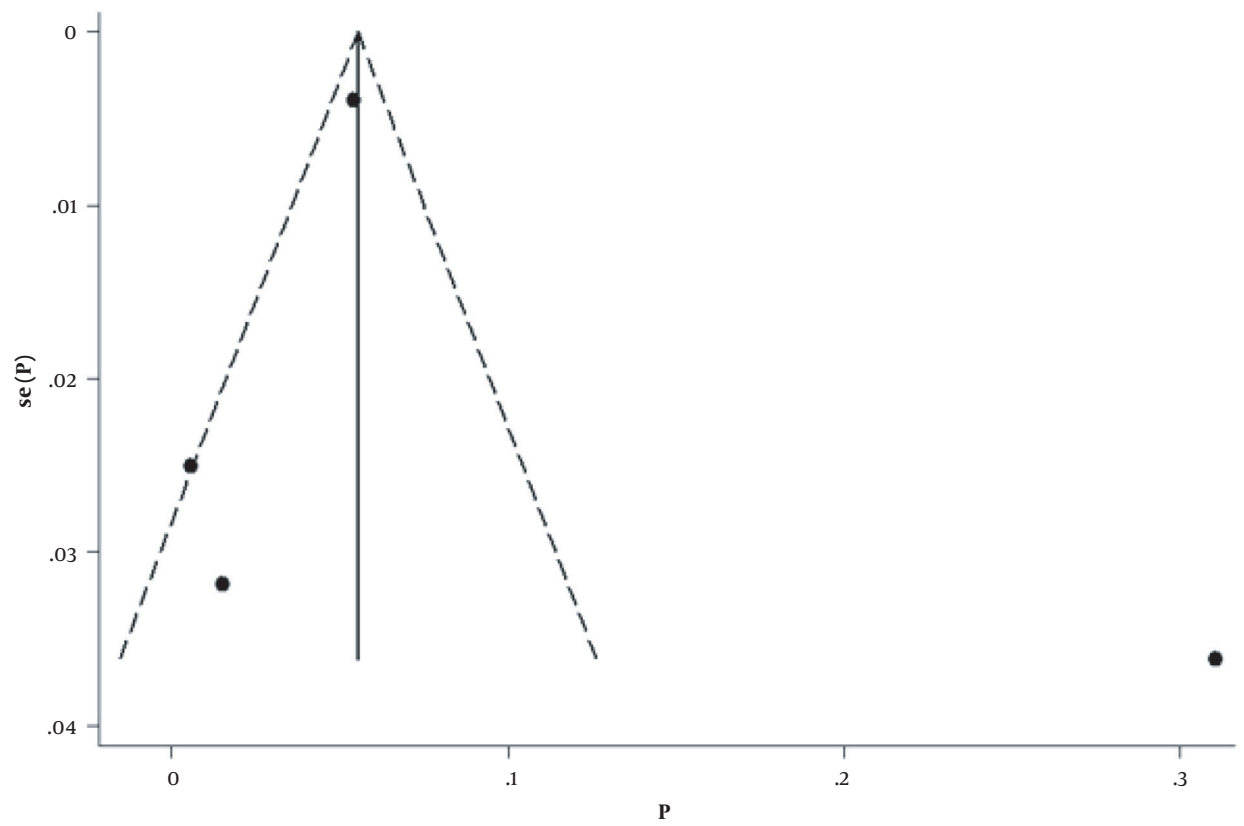

Figure 5. Funnel plot for dioxin exposure and breast cancer (funnel chart with pseudo 95\% confidence limits) in case-control studies

dioxins and standardized mortality rates (SMRs) were determined.

\section{Footnotes}

Authors' Contribution: Concept and design; Nematollah Jaafarzadeh Haghighi. Analysis of data: Amal Saki Malehi. Writing of the manuscript and revision; Nematollah Jaafarzadeh Haghighi, Zeinab Ghaedrahmat, and Amal Saki Malehi.

Conflict of Interests: Authors declare no conflicts of interest.

Funding/Support: The funding resources of the present study were provided by Shoushtar Faculty of Medical Sciences.

\section{References}

1. Baan R, Grosse Y, Straif K, Secretan B, El Ghissassi F, Bouvard V, et al. A review of human carcinogens-Part F: chemical agents and related occupations. Lancet Oncol. 2009;10(12):1143-4. doi: 10.1016/s14702045(09)70358-4. [PubMed:19998521].

2. International Agency for Research on Cancer. Polychlorinated dibenzopara-dioxins and polychlorinated dibenzofurans. IARC monographs on the evaluation of carcinogenic risks to humans. $1997.10 \mathrm{p}$.

3. Mandal PK. Dioxin: a review of its environmental effects and its aryl hydrocarbon receptor biology. J Comp Physiol B. 2005;175(4):221-30. doi: 10.1007/s00360-005-0483-3. [PubMed: 15900503].
4. Brunnberg S, Andersson P, Poellinger L, Hanberg A. The constitutively active Ah receptor (CA-AhR) mouse as a model for dioxin exposure - effects in reproductive organs. Chemosphere. 2011;85(11):1701-6. doi: 10.1016/j.chemosphere.2011.09.015. [PubMed: 22014662].

5. M Hall J. The Aryl-hydrocarbon Receptor (AhR) as a Therapeutic Target in Human Breast Cancer. J Steroids Hormon Sci. 2013;5(3). doi: 10.4172/2157-7536.1000140.

6. Safe S, Lee SO, Jin UH. Role of the aryl hydrocarbon receptor in carcinogenesis and potential as a drug target. Toxicol Sci. 2013;135(1):116. doi: 10.1093/toxsci/kft128. [PubMed: 23771949]. [PubMed Central: PMC3748760].

7. Soto AM, Sonnenschein C. Environmental causes of cancer: endocrine disruptors as carcinogens. Nat Rev Endocrinol. 2010;6(7):36370. doi: 10.1038/nrendo.2010.87. [PubMed: 20498677]. [PubMed Central: PMC3933258].

8. Treich I, Cairns BR, de los Santos T, Brewster E, Carlson M. SNF11, a new component of the yeast SNF-SWI complex that interacts with a conserved region of SNF2. Mol Cell Biol. 1995;15(8):4240-8. doi: 10.1128/MCB.15.8.4240. [PubMed: 7623818]. [PubMed Central: PMC230663].

9. Ohtake F, Takeyama K, Matsumoto T, Kitagawa H, Yamamoto Y, Nohara $\mathrm{K}$, et al. Modulation of oestrogen receptor signalling by association with the activated dioxin receptor. Nature. 2003;423(6939):54550. doi: 10.1038/nature01606. [PubMed:12774124].

10. Milbrath MO, Wenger Y, Chang CW, Emond C, Garabrant D, Gillespie BW, et al. Apparent half-lives of dioxins, furans, and polychlorinated biphenyls as a function of age, body fat, smoking status, and breast-feeding. Environ Health Perspect. 2009;117(3):417-25. doi: 10.1289/ehp.11781. [PubMed: 19337517]. [PubMed Central: PMC2661912].

11. Arisawa K, Matsumura T, Tohyama C, Saito H, Satoh H, Nagai M, et al. Fish intake, plasma omega-3 polyunsaturated fatty acids, and polychlorinated dibenzo-p-dioxins/polychlorinated dibenzo-furans and co-planar polychlorinated biphenyls in the blood of the Japanese 
population. Int Arch Occup Environ Health. 2003;76(3):205-15. doi: 10.1007/s00420-002-0400-y. [PubMed: 12690495].

12. Sonawane BR. Chemical contaminants in human milk: an overview. Environ Health Perspect. 1995;103 Suppl 6:197-205. doi: 10.1289/ehp.95103s6197. [PubMed: 8549474]. [PubMed Central: PMC1518901].

13. Papillomaviruses H. IARC monographs on the evaluation of carcinogenic risks to humans. Lyon, France: IARC; 2011.

14. Consonni D, Sindaco R, Bertazzi PA. Blood levels of dioxins, furans, dioxin-like PCBs, and TEQs in general populations: a review, 1989-2010. Environ Int. 2012;44:151-62. doi:10.1016/j.envint.2012.01.004. [PubMed: 22364893].

15. di Domenico A, Cerlesi S, Ratti S. A two-exponential model to describe the vanishing trend of 2,3,7,8-tetrachlorodibenzodioxin (TCDD) in the soil at Seveso, northern Italy. Chemosphere.1990;20(10-12):1559-66. doi:10.1016/0045-6535(90)90313-i.

16. Brody JG, Moysich KB, Humblet O, Attfield KR, Beehler GP, Rudel RA. Environmental pollutants and breast cancer: epidemiologic studies. Cancer. 2007;109(12 Suppl):2667-711. doi: 10.1002/cncr.22655. [PubMed: 17503436]

17. Kogevinas M. Human health effects of dioxins: cancer, reproduc tive and endocrine system effects. Apmis. 2001;109(S103):S223-32. doi: 10.1111/j.1600-0463.2001.tb05771.x.

18. Moher D, Liberati A, Tetzlaff J, Altman DG, Prisma Group. Preferred reporting items for systematic reviews and meta-analyses: the PRISMA statement. PLoS Med. 2009;6(7). e1000097. doi: 10.1371/journal.pmed.1000097. [PubMed:19621072]. [PubMed Central: PMC2707599].

19. Danjou AM, Fervers B, Boutron-Ruault M, Philip T, Clavel-Chapelon F, Dossus L. Estimated dietary dioxin exposure and breast cancer risk among women from the French E3N prospective cohort. Breast Cancer Res. 2015;17(1). doi:10.1186/s13058-015-0536-9.

20. Reynolds P, Hurley SE, Petreas M, Goldberg DE, Smith D, Gilliss D, et al. Adipose levels of dioxins and risk of breast cancer. Cancer Causes Control. 2005;16(5):525-35. doi: 10.1007/s10552-004-7840-5. [PubMed 15986107].

21. Manuwald U, Velasco Garrido M, Berger J, Manz A, Baur X. Mortality study of chemical workers exposed to dioxins: follow-up 23 years af ter chemical plant closure. Occup Environ Med.2012;69(9):636-42. doi 10.1136/oemed-2012-100682. [PubMed: 22767868].

22. Korner W, Hanf V, Faust A, Temmen R, Tinneberg HR, Hagenmaier $\mathrm{H}$. Concentrations and profiles of PCDDs and PCDFs in human mammary carcinoma tissue. Chemosphere. 1994;29(9-11):2339-47. doi: 10.1016/0045-6535(94)90402-2. [PubMed: 7850382].

23. Villeneuve S, Cyr D, Lynge E, Orsi L, Sabroe S, Merletti F, et al. Occupation and occupational exposure to endocrine disrupting chemicals in male breast cancer: a case-control study in Europe. Occup Environ Med.2010;67(12):837-44. doi:10.1136/oem.2009.052175. [PubMed: 20798010]. [PubMed Central: PMC3151527].

24. Dai D, Oyana TJ. Spatial variations in the incidence of breast cancer and potential risks associated with soil dioxin contamination in Midland, Saginaw, and Bay Counties, Michigan, USA. Environ Health. 2008;7(1). doi: 10.1186/1476-069x-7-49.

25. Viel JF, Clement MC, Hagi M, Grandjean S, Challier B, Danzon A. Dioxin emissions from a municipal solid waste incinerator and risk of invasive breast cancer: a population-based case-control study with GISderived exposure. Int J Health Geogr. 2008;7:4. doi: 10.1186/1476-072X7-4. [PubMed: 18226215]. [PubMed Central: PMC2267447].

26. Warner M, Eskenazi B, Mocarelli P, Gerthoux PM, Samuels S, Needham L, et al. Serum dioxin concentrations and breast cancer risk in the Seveso Women's Health Study. Environ Health Perspect. 2002;110(7):625-8. doi: 10.1289/ehp.02110625. [PubMed: 12117637]. [PubMed Central: PMC1240906].

27. Wang SL, Chang YC, Chao HR, Li CM, Li LA, Lin LY, et al. Body burdens of polychlorinated dibenzo-p-dioxins, dibenzofurans, and biphenyls and their relations to estrogen metabolism in pregnant women. Environ Health Perspect. 2006;114(5):740-5. doi: 10.1289/ehp.8809. [PubMed: 16675430]. [PubMed Central: PMC1459929].

28. Danjou AMN, Coudon T, Praud D, Leveque E, Faure E, Salizzoni P, et al. Long-term airborne dioxin exposure and breast cancer risk in a casecontrol study nested within the French E3N prospective cohort. Environ Int. 2019;124:236-48. doi: 10.1016/j.envint.2019.01.001. [PubMed: 30658268].

29. Macon MB, Fenton SE. Endocrine disruptors and the breast: early life effects and later life disease. J Mammary Gland Biol Neoplasia. 2013;18(1):43-61. doi: 10.1007/s10911-013-9275-7. [PubMed: 23417729]. [PubMed Central: PMC3682794]. 